\title{
Anti-prolactin Agent with Gonadotropin-releasing Hormone Synergistically Improve Egg Production in Indigenous Chicken via Regulating Broody Behavior
}

Deabasish Barman, Sumon Sarkar, Mst. Misrat Masuma Parvez, Md. Mahmudul Hasan, Fahima Binthe Aziz, Rakibul Islam, Soshe Ahmed, Md. Hakimul Haque, and Md. Bazlar Rashid

\section{ABSTRACT}

Despite the indigenous chicken's many natural advantages, broodiness continues to be a substantial barrier to minimizing egg production and economic losses. Prolactin is the primary regulator of broodiness. As a result, the goal of our research was to see if lower prolactin levels can limit broodiness, resulting in increased egg production and increased economic value. Sixty indigenous chickens aged 18-20 weeks were divided into three groups of 20 hens each. One was left untreated, two were given GnRH (0.50 ml/bird @ S/C) with Anti-prolactin (Bromocriptine 640 g/bird/day @ orally), and three were given GnRH, Anti-prolactin, and cold therapy (1 time/day) for three months. The chickens were first given GnRH injections once a week for three weeks. It was given on the 13th day of egg production and continued for 10 days. After utilizing GnRH plus anti-prolactin medications for 13 days, the cold application was given every day at the same time. Hormone analysis, egg production, broody time, pause time was noted. Prolactin levels fell in all treatment groups. The number of egg production per clutch was significantly $(\mathbf{p}<0.05)$ increased in both treated groups, and the highest was recorded in GnRH plus anti-prolactin group (33eggs / clutch). Surprisingly, pause day and broody time significantly $(p<0.05)$ decreased in the same Group B $(7 d, 4 d$ respectively). Postmortem ovary analysis substantially supports the treatment group's finding against the control group. Overall, combining an anti-prolactin drug with GnRH enhances egg production by synergistically modulating broody behavior.

Keywords: Anti-prolactin, broodiness, pause day, egg production, indigenous chicken.
Submitted : January 31, 2022

Published : February 25, 2022

ISSN: $2684-1827$

DOI: 10.24018 /ejfood.2022.4.1.456

Deabasish Barman

Department of Physiology and Pharmacology, Hajee Mohammad Danesh Science and Technology University, Bangladesh.

(e-mail: deabashadhen@gmail.com)

Sumon Sarkar

Department of Physiology and Pharmacology, Hajee Mohammad Danesh Science and Technology University, Bangladesh.

(e-mail: sarkarsumon.setu@gmail.com)

Mst. Misrat Masuma Parvez

Department of Physiology and Pharmacology, Hajee Mohammad Danesh Science and Technology University, Bangladesh.

(e-mail: parvez.misrat@gmail.com)

Md. Mahmudul Hasan

Department of Physiology and

Pharmacology, Hajee Mohammad Danesh

Science and Technology University, Bangladesh.

(e-mail: m.hasanvet@gmail.com)

Fahima Binthe Aziz

Department of Physiology and Pharmacology, Hajee Mohammad Danesh Science and Technology University, Bangladesh.

(e-mail: fbarumana07@gmail.com)

Rakibul Islam

Department of Physiology and Pharmacology, Hajee Mohammad Danesh Science and Technology University, Bangladesh.

(e-mail: rislam@hstu.ac.bd)

Soshe Ahmed

Department of Veterinary and Animal

Sciences, University of Rajshahi,

Bangladesh.

(e-mail: soshe.ahmed@gmail.com)

Md. Hakimul Haque

Department of Veterinary and Animal

Sciences, University of Rajshahi,

Bangladesh.

(e-mail: hakim.ahvs ${ }^{\circledR}$ ru.ac.bd)

Md. Bazlar Rashid*

Department of Physiology and

Pharmacology, Hajee Mohammad Danesh

Science and Technology University,

Bangladesh.

(e-mail: bazlar116@hstu.ac.bd)

*Corresponding Author 


\section{INTRODUCTION}

The development of the poultry sector, which contributes directly to the economy on a national and worldwide basis, is centered on reproduction research. High reproductive success in laying chickens requires increased egg output. Commercial layers are genetically pre-settled to produce eggs continuously without broodiness during the egg-laying process. In contrast, indigenous laying hens spend a significant amount of time brooding between egg laying periods, resulting in lower egg output and significant economic loss. Increased egg production in indigenous hens continues to be hampered by broodiness. However, only a little amount of research has been done on the development of indigenous chicken eggs.

The physiological involvement of prolactin (PRL) in the commencement of incubation in hens has been extensively documented [1]-[3]. Broodiness has been linked to an increase in plasma PRL levels [4]. PRL mRNA reaches its greatest level [5], implying that PRL is required for broodiness maintenance. In poultry, an anti-prolactin medication (Bromocriptin) has been proven to reduce prolactin levels. Subcutaneous treatment of bromocriptine to white leghorn birds from 17 to 36 weeks suppressed prolactin secretion and increased egg production up to 72 weeks in a single reproductive cycle [6]. Anti-prolactin medicines combined with peppermint supplementation have been shown in our lab to drastically minimize the broody time and boost sound quality egg production [7]. Another study found that combining anti-prolactin medications with laying hen serum dramatically lowers the broody period while increasing egg production [8].

Gonadotropin hormone and prolactin surge have negatively related to each other. Decrease surge of GnRH (Gonadotropin hormone-releasing hormone) effectively increases prolactin secretion. Earlier studies revealed [6] that prolactin inhibits gonadotrophin stimulated ovulation and estrogen production at the ovarian level in chicken. A decrease in prolactin is found before and during the preovulatory LH surge [9]. It is also being reported that the visual image of egg and chick negatively stimulates the hypothalamus to release $\mathrm{GnRH}$, resulting in increased secretion of prolactin that develops broodiness. Moreover, the feeling of eggs and chicks in the breast muscle in hen has been seemed to stimulate prolactin release resulting in broodiness development. Therefore, our study hypotheses that decreased prolactin levels suppress broodiness, resulting in higher egg production and upholding economic profit. Application of GnRH and cold therapy also inhibit prolactin and enhance steroid hormone for more egg production.

\section{MATERIALS AND METHODS}

\section{A. Placement and Duration}

This research work was performed at Bochaganj Upazila of Dinajpur district, Bangladesh, under the Department of Physiology and Pharmacology at Hajee Mohammad Danesh Science \& Technology University for 12 months from July 2020 to June 2021.

\section{B. Ethics Statement}

Animal experiments were performed following the Guiding Principles for the Care and Use of Research Animals under the final approval of the Animal Experiments Ethics Committee of Hajee Mohammad Danesh Science \& Technology University and laws of Bangladesh Veterinary Council, Bangladesh.

\section{Placement and Duration Collection and Management of Chickens}

Sixty indigenous chickens of 18-20 weeks of age were randomly assigned into three groups, consisting of 20 hens. $1^{\text {st }}$ one was untreated as the control group, $2^{\text {nd }}$ was treated with GnRH (0.50 ml/bird@ S/C) plus Anti-prolactin drug (Bromocriptine $640 \mu \mathrm{g} / \mathrm{bird} /$ day @ orally), and $3^{\text {rd }}$ was treated GnRH, Anti-prolactin plus cold therapy (1 time/ day) for three months. All treated grouped chicken first received $\mathrm{GnRH}$ injection once a week for three weeks. Anti-prolactin was given on the 13th day of egg production for the next ten days. The cold application was given every day at a fixed time after using GnRH plus anti-prolactin drugs from day $13^{\text {th }}$ of egg production. All the birds were housed under standard husbandry conditions and reared in a semiscavenging system. A balanced ration and ad-libitum water supply were ensured throughout the experimental period.

\section{Application of Drug to the Chicken}

Synthetic Gonadotropin-releasing hormone (Ovurelin ${ }^{\circledR}$ ) and anti-prolactin drug (Bromocriptine $\left.{ }^{\circledR}\right)$ were purchased from the local market. At first, drugs were collected and ground with pestle and mortar for processing and dose adjustment. The dose of drugs was selected according to our previous work [7], [8]. All experimental chicken was grouped into control and treated. Treated grouped chicken, received $\mathrm{GnRH}$ injection once a week for three consequent weeks. Anti-prolactin drug was given on the 13th day of egg production up to the next ten days. Control grouped chicken was kept without treatment of $\mathrm{GnRH}$ and Anti-prolactin drug.

\section{E. Application of Cold Therapy}

Feeling of egg and chicks in the breast muscle in hen has been seemed to stimulate prolactin release resulting broodiness development. Therefore, the cold application was given to the treated hens every day at a fixed time after using anti-prolactin drugs from day $13^{\text {th }}$ of egg production.

\section{F. Clinical Observation of Chicken}

The effect of the anti-prolactin drug in the combination of $\mathrm{GnRH} /$ Cold therapy, serum on egg production, pause days, hormonal parameters, body weight, and egg quality was recorded.

\section{1) Egg Production Record}

Egg production was recorded for each hen simultaneously during the laying period. In addition, the incidence of broken eggs and soft-shelled eggs was identified and recorded.

\section{2) Observation of Egg Quality}

Egg qualities were measured from those eggs laid by hens of different treatment groups. Measured egg qualities were egg weight, dry shell weight, fresh albumin weight, fresh 
yolk weight, eggshell thickness, the height of the thick albumen, the yolk's height, the yolk's width, the width of the egg, and diameter of the egg albumen. For quality determination, egg weight was recorded by an electric weighing balance. Next, slide calipers measured the length and width of the egg. The eggs will then carefully break down on a glass plate $(40 \times 20 \mathrm{~cm})$ to determine the internal egg qualities.

\section{3) Prolactin Hormone Assay}

Plasma prolactin level measured from plasma isolated from blood throughout the experiment by Radioimmunoassay technique (RIA) accordingly as previous [8]. The blood sample was collected from the experimental birds before and after treatment; then plasma was separated from whole blood RIA was performed according to manufacturer instruction.

\section{4) Postmortem analysis}

Experimental birds from all groups were sacrificed to investigate the reproductive tract to find any significant difference between treated and control groups. In addition, the sample from the ovary and uterus was kept for further histopathological analysis to observe the significant changes at the cellular level.

\section{G. Cost-benefit analysis}

The cost-benefit analysis was done from the recoded data by using the statistical formula to see whether the approach was profitable or not.

\section{H. Statistical analysis}

Data were presented as Mean \pm SEM. Statistical analysis was performed using SPSS software version 14.0 (SPSS Inc., Chicago, USA). The student's t-test was applied to compare the data between two groups. In addition, one-way ANOVA was done to compare the data of more than two groups. $P$ values $<0.05$ were considered to be statistically significant.

\section{RESULTS}

A. GnRH, Anti-prolactin, and the Cold Application Does Not Affect the Weight Gain of the Laying Bird during the Laying Period

We wanted to see if the weight of the bird gained when different treatments were applied during the laying stage. Although body weight was evaluated before and after treatment in comparison to control birds, no significant weight gain was seen in the treated birds (Fig. 1).

\section{B. GnRH, Anti-prolactin, and Cold Therapy Effectively Reduces Prolactin Hormone Concentration in Plasma}

During the laying period, we looked to see if the concentration of prolactin hormone in blood plasma dropped. Prolactin hormone levels were examined before and after treatment in treated birds compared to control birds, and all treated birds had significantly lower prolactin hormone concentrations in plasma (Fig. 2).

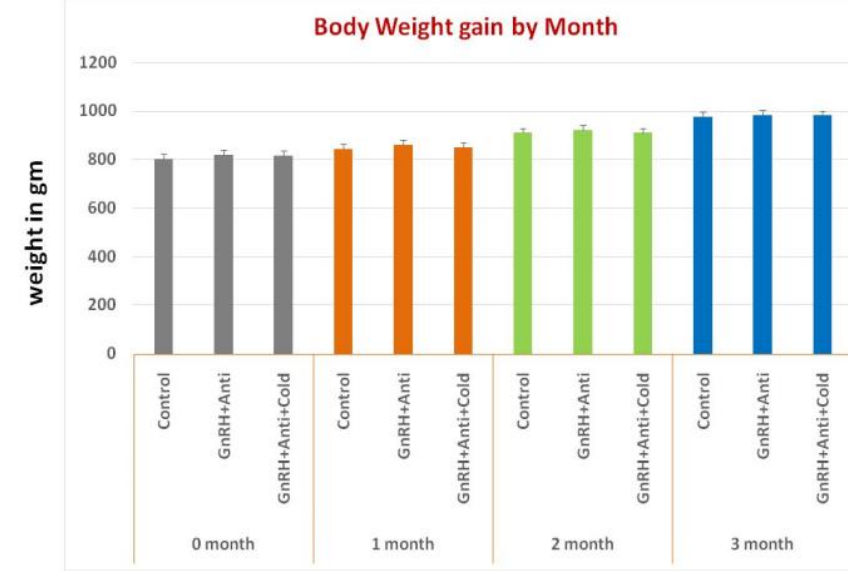

Fig. 1. GnRH, Anti-prolactin and cold application does not affect weight gain of the laying bird during laying period. Birds without treatment serve as control. Relative body weight measured in gram. Data were presented as

Mean \pm SEM. Different bar color indicate progressive different month.

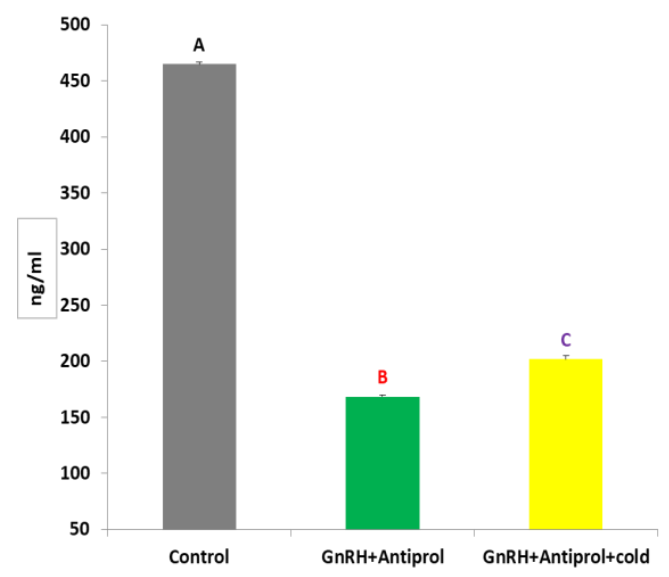

Fig. 2. GnRH, Anti-prolactin, and cold therapy significantly reduce prolactin hormone concentration in plasma. Data were presented as Mean \pm SEM. Different letters denote significant difference at $P<0.05$ level, when compared to the control.

\section{GnRH with Anti-prolactin Drugs Significantly} Increase the Egg Production per Clutch

GnRH, anti-prolactin medications and cold application were used to examine if they boosted egg production in native chicken. The total number of eggs per clutch was calculated in comparison to the control hen. The number of eggs produced per clutch rose significantly $(\mathrm{p}<0.05)$ in both treated groups (Fig. 3A), with the highest number (33 eggs / clutch) in the GnRH plus Antiprolactin group. Furthermore, postmortem study of ovarian state substantially indicates increased egg production per clutch (Fig. 3B).

\section{GnRH with Anti-prolactin Drugs Significantly Decreased the Pause Time and Broody Time}

Compared to control hens, we looked at whether GnRH, anti-prolactin medicines, and cold application reduced pause and broody time in indigenous chickens. Both treatment groups saw a significant $(\mathrm{p}<0.05)$ decrease in pause and broody time, with the GnRH plus Antiprolactin group having the lowest (Fig. 4A). The observation of ovary status using postmortem analysis proved that observation (Fig. 4B). 
(A)

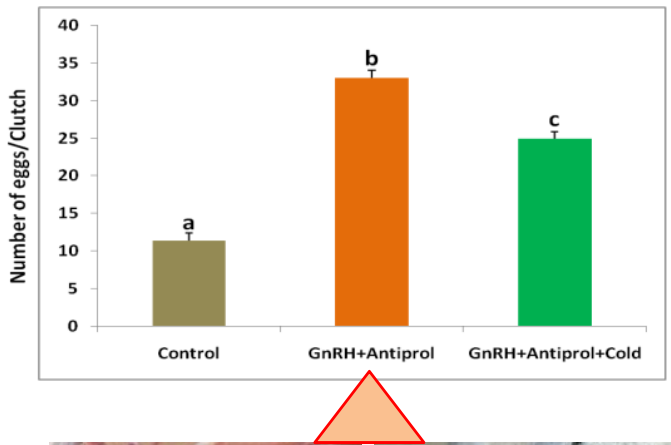

(B)

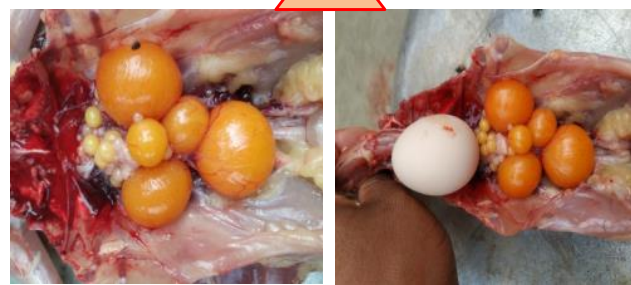

Presence of mature and growing ova in the ovary on 32th day of eggs laying on treatment

Fig. 3. A. GnRH, anti-prolactin and cold application significantly $(p<0.05)$ increase egg production per clutch. Birds without treatment serve as control. Relative number of eggs per clutch. Data were presented as Mean \pm SEM. Different letters denote significant difference at $P<0.05$ level, when compared to the control. B. Postmortem examination of the ovary of the treated hen during laying period. Mature and growing ova present in the ovary.

(A)

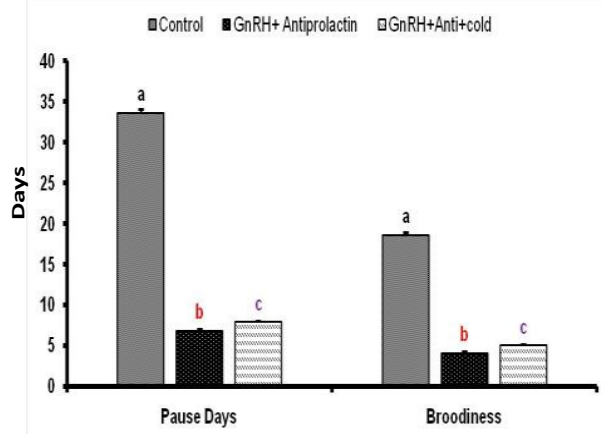

(B)
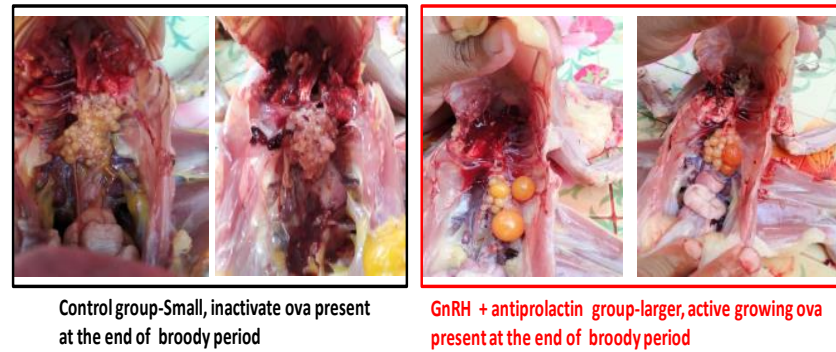

presentat the end of broody period

Fig. 4. A. GnRH, anti-prolactin and cold application significantly $(\mathrm{p}<0.05)$ decreased pause time and broody time. Birds without treatment served as control. A relative number of days taken by for broodiness and pause time. Data are presented as Mean \pm SEM. Different letters denote significant differences at $P<0.05$ level compared to the control. B. Postmortem examination of the ovary of the treated hen at the end of the broody period. In the control group- small, inactivate ova in the ovary and in the GnRH plus anti-prolactin group-larger, active growing ova present in the ovary.

\section{E. Treatment of Indigenous Chicken with Different Drugs Return More Profit Compared to Control Hen}

We looked into whether raising egg number and shortening broody time with GnRH, anti-prolactin medicines, and cold application yielded more profit.
Treatment of native chickens with various medications yields higher profits than control hens (Table I).

TABLE I: COST-BENEFIT ANALYSIS OF HENS OF DIFFERENT GROUPS TREATED WITH DIFFERENT DRUGS. GNRH PLUS ANTIPROLACTIN SHOWS MAXIMUM BENEFIT AMONG OTHER GROUPS

\begin{tabular}{|c|c|c|c|c|}
\hline Source & Items & Control & $\begin{array}{l}\text { GnRH plus } \\
\text { Antiprolactin }\end{array}$ & $\begin{array}{c}\text { GnRH } \\
\text { Antiprolactin } \\
\text { plus Cold }\end{array}$ \\
\hline \multirow[t]{12}{*}{$\begin{array}{l}\text { Expend- } \\
\text { iture }\end{array}$} & $\begin{array}{l}\text { Cost of } \\
\text { hens }\end{array}$ & $\begin{array}{c}225 / \mathrm{hen} \times 20=4 \\
500 \mathrm{tk}\end{array}$ & $\begin{array}{l}230 / \text { hen } \times 20 \\
=4600 \mathrm{tk}\end{array}$ & $\begin{array}{l}228 / \text { hen } \times 20 \\
=4560\end{array}$ \\
\hline & $\begin{array}{l}\text { Feed } \\
\text { cost/hen }\end{array}$ & $\begin{array}{l}2 \mathrm{tk} / \text { day } \times 2 \times 85 \\
\quad=170 \mathrm{tk}\end{array}$ & $\begin{array}{l}2 \mathrm{tk} / \text { day } \times 2 \times 85 \\
\quad=170 \mathrm{tk}\end{array}$ & $\begin{array}{c}2 \mathrm{tk} / \text { day } \times 2 \times 85 \\
\quad=170 \mathrm{tk}\end{array}$ \\
\hline & Total feed & $2 \times 85 \times 20$ & $2 \times 85 \times 20$ & $2 \times 85 \times 20$ \\
\hline & cost & $=3400 \mathrm{tk}$ & $=3400 \mathrm{tk}$ & $=3400 \mathrm{tk}$ \\
\hline & $\begin{array}{c}\text { GnRH } \\
\text { cost/hen }\end{array}$ & $\times$ & $\begin{array}{c}17.5(0.25 \mathrm{ml}) \times 3 \\
=52.5 \mathrm{tk}\end{array}$ & $\begin{array}{c}17.5(0.25 \mathrm{ml}) \\
\times 2=35 \mathrm{tk}\end{array}$ \\
\hline & $\begin{array}{c}\text { Total GnRH } \\
\text { cost }\end{array}$ & $\times$ & $\begin{array}{c}17.5 \times 3 \times 20 \\
=1050 \mathrm{tk}\end{array}$ & $\begin{array}{c}17.5 \times 2 \times 20 \\
=700 \mathrm{tk}\end{array}$ \\
\hline & $\begin{array}{l}\text { Brocpt. } \\
\text { cost/hen }\end{array}$ & $\times$ & $\begin{array}{l}4(1 / 3 p) \times 7 \\
\quad=28 \mathrm{tk}\end{array}$ & $\begin{array}{l}4(1 / 3 p) \times 7 \\
\quad=28 \mathrm{tk}\end{array}$ \\
\hline & $\begin{array}{c}\text { Total } \\
\text { Brocpt. } \\
\text { cost }\end{array}$ & $\times$ & $\begin{array}{l}4 \times 7 \times 20 \times 2 \\
=1120 \mathrm{tk}\end{array}$ & $\begin{array}{c}4 \times 7 \times 20 \times 2 \\
=1120 \mathrm{tk}\end{array}$ \\
\hline & Cold & $\times$ & $x$ & $0 \mathrm{tk}$ \\
\hline & Total cost & $225+170$ & $(230+170+52.5$ & $(228+170+35$ \\
\hline & /hen & $=395 \mathrm{tk}$ & $+56)=508.5 \mathrm{tk}$ & $+56)=489 \mathrm{tk}$ \\
\hline & Total cost & $\begin{array}{c}4500+3400 \\
=7900 \mathrm{tk}\end{array}$ & $\begin{array}{c}(4600+3400+10 \\
50+1120) \\
=10170 \mathrm{tk}\end{array}$ & $\begin{array}{c}(4560+3400+7 \\
00+1120) \\
=9780 \mathrm{tk}\end{array}$ \\
\hline \multirow[t]{7}{*}{ Income } & Egg/hen & $24 \times 10=240 \mathrm{tk}$ & $72 \times 10=720 \mathrm{tk}$ & $65 \times 10=650 \mathrm{tk}$ \\
\hline & Total egg & $24 \times 10 \times 20$ & $72 \times 10 \times 20$ & $65 \times 10 \times 20$ \\
\hline & Sell of hen & $\begin{array}{c}273.5 \\
(280 \mathrm{tk} / \mathrm{kg})\end{array}$ & $\begin{array}{c}275.5 \\
(280 \mathrm{tk} / \mathrm{kg})\end{array}$ & $\begin{array}{c}275 \\
(280 \mathrm{tk} / \mathrm{kg})\end{array}$ \\
\hline & $\begin{array}{c}\text { Total } \\
\text { income from } \\
\text { hen sell }\end{array}$ & $\begin{array}{l}273.5 \times 20 \\
=5470 \mathrm{tk}\end{array}$ & $\begin{array}{l}275.5 \times 20 \\
=5510 \mathrm{tk}\end{array}$ & $\begin{array}{l}275 \times 20 \\
=5500 \mathrm{tk}\end{array}$ \\
\hline & Total & $240+273.5$ & $720+275.5$ & $650+275$ \\
\hline & income /hen & $=513.5 \mathrm{tk}$ & $=995.5 \mathrm{tk}$ & $=925 \mathrm{tk}$ \\
\hline & Total & $10270 \mathrm{tk}$ & 19910tk & $18500 \mathrm{tk}$ \\
\hline Profit & $\begin{array}{l}\text { Income- } \\
\text { Expenditu } \\
\text { re }\end{array}$ & $\begin{array}{c}10270- \\
7900=2370 \mathrm{tk}\end{array}$ & $\begin{array}{l}19910-10170 \\
=9740 \mathrm{tk}\end{array}$ & $\begin{array}{c}18500-9780 \\
=8720 \mathrm{tk}\end{array}$ \\
\hline Net profit & $\begin{array}{l}\text { Profit-No } \\
\text { of hen }\end{array}$ & $\begin{array}{l}2370-20 \\
=2350 \mathrm{tk}\end{array}$ & $\begin{array}{l}9740-20 \\
=9720 \mathrm{tk}\end{array}$ & $\begin{array}{l}8720-20= \\
8700 \text { tk }\end{array}$ \\
\hline Profit/hen & & $117.5 \mathrm{tk}$ & 486tk & 436tk \\
\hline
\end{tabular}

\section{DISCUSSION}

Our result showed that treatment of indigenous laying hens with GnRH plus anti-prolactin significantly $(\mathrm{p}<0.05)$ increased the number of egg production per clutch (33 eggs/clutch). At the same time, oppositely, pause day and broody time also significantly $(\mathrm{p}<0.05)$ decreased in the same treated group $\left(7^{\text {th }} \mathrm{d}, 4^{\text {th }} \mathrm{d}\right.$, respectively). Cold treatments have also considerably impacted egg production, pause days, and broody times. The finding reported in the treatment group compared to the control group is substantially supported by ovary status analysis following postmortem inspection. This conclusion is supported by earlier research [7].

Furthermore, we found that anti-prolactin medications containing peppermint and anti-prolactin drugs with serum supplements significantly reduced the pause day and broody duration [7], [8]. When the birds were regularly given antiprolactin medicines (bromocriptin), their plasma prolactin levels were lower than when they were not. This is consistent with a previous study in which prolactin levels were shown to be lower in indigenous chickens taking similar medicines [7], [8]. Subcutaneous injection of 
bromocriptine to white leghorn birds from 17 to 36 weeks of age suppressed prolactin secretion and increased egg production up to 72 weeks in one reproductive cycle [6]. The broody behavior observed in our study is dramatically reduced when prolactin levels are reduced.

It has been reported that a decreased surge of GnRH effectively increases prolactin secretion. Therefore, GnRH application to the bird and anti-prolactin synergistically improves eggs production by reducing broody time and pause time. Earlier studies [6] revealed that prolactin inhibits gonadotrophin stimulated ovulation and estrogen production at the ovarian level in chicken. A decreased prolactin level is found before and during the pre-ovulatory LH surge [9]. Crisostomeet al. [10] reported that implicating increased prolactin secretion as the cause of reduced circulating gonadotropins, ovarian regression, and the shift from egg-laying to the incubation phase of the reproductive cycle in the hen. But prolactin hormone reduces the more extended sequence by the rapid growth of follicles in the ovary. Prolactin interferes the follicular steroidogenesis in avian species [11]-[13]. So, in the current study, we used anti-prolactin to reduce the high concentration of prolactin and kept minimal amounts are required for average growth. Prolactin at high levels suppresses the FSH-induced estradiol production through the aromatase enzyme system [14], resulting in reduced steroidogenic potential within the follicles. However, this reduced steroidogenic potential cannot produce progesterone sufficient to elicit positive feedback of LH required for ovulation [15]. In this study, we have used GnRH to make or secrete LH and FSH hormones, in which FSH helps stimulate the ovary to produce more follicles production and mature ova for ovulation. In addition, the prolactin hormone supports pause and broodiness. So, we treated with the anti-prolactin drug bromocriptine, which negatively affected delay and broodiness. Also, GnRH, Anti- prolactin, and cold-treated birds have more yellow yolk follicles than the control group. This may explain the cause for longer sequences and reduced laying pauses in the treated birds; however, the occurrences of not more than seven days of applying pause in birds of both groups.

\section{CONCLUSION}

Overall, our findings show that combining $\mathrm{GnRH}$ (ovurelin) with anti-prolactin (bromocriptine) enhances egg production in Indigenous birds. Broodiness and pause days, on the other hand, are reduced. In the treated birds, GnRH with anti-prolactin results in longer egg sequences and condensed broody with pauses. More research is needed to learn more about the underlying process that enhances egg production by researching biochemical and hormonal factors.

\section{ACKNOWLEDGEMENT}

The authors would like to express their most profound sense of gratitude and sincere thanks to the institute of research and training (IRT), Hajee Mohammad Danesh Science and Technology University, Bangladesh.

\section{CONFLICT OF INTEREST}

The authors declare no conflict of interest.

\section{REFERENCES}

[1] Ohkubo T, Tanaka M, Nakashima K, Talbot RT, Sharp PJ.Prolactin receptor gene expression in the brain and peripheral tissues in broody and non-broody breeds of domestic hen. Gen Comp Endocrinol. 1998 ; 109:60-68.

[2] March JB, Sharp PJ, Wilson PW, Sang HM. Effect of active immunization against recombinant derived chicken prolactin fusion protein on the onset of broodiness and photoinduced egg laying in bantam hens. J ReprodFerti. 1994; 101:227-233.

[3] Sharp PJ, Macnamee MC, Sterling RJ, Lea RW, Pedersen HC. Relationship between prolactin, luteinizing homone and broody behavior in bantam hens. J Endocrinol. 1988; 118: 279-286.

[4] Bacon WL, Burke WH, Nestor KE, Brown KI. Influence of genetic increases in egg production on traits associated with broodiness in turkeys. Poult Sci. 1983; 62: 2460-2473.

[5] Karatzas CN, Guemene D, Zadworny D, Kuhnlein U. Changes in expression of the prolactin and growth hormone gene during different reproductive stages in the pituitary gland of turkeys. ReprodNutr Dev. 1997; 37: 69-79.

[6] Reddy IJ, David CG, Sarma PV, Singh K. Prolactin hormone and inter sequence pause days in domestic chicken. Vet Rec. 2001; 149: 590-592.

[7] Parvez MM, Islam R, Rashid MB, Hasan MM, Mobarak H, Kumar K. et al., Roy and Md. Anowarul Haque (2017). Effect of serum from laying hen and antiprolactin drug on egg production of indigenous chicken in Bangladesh. Asian Australa J Biosci Biotechnol.2017; 2(1): $51-54$

[8] Banu MN, Rashid MB, Hasan MM, Aziz FB, Islam MR,Haque MA. Effect of anti-prolactin drug and eppermint on broodiness, laying performance and egg quality in indigenous hens. Asian J Med Bio Res. 2016; 2(4): 547-554.

[9] Zadworny D, Walton JS, Etches RJ. Effect of feed and water deprivation or force feeding onplasma prolactin concentration in turkey hens. BiolReprod. 1985; 332:241-247.

[10] Crisostomoe S, Guemene D. Garreau-Mills M. Morvan C, Zadworny D. Prevention of incubation behavior expression in turkey hens by active immunization against prolactin. Theriogetnology. 1998; 50: 675-690.

[11] Dajee M. Fely GH, \& Richards JS. (1998). Stat 5b and the orphan nuclear receptors regulate expression of the alpha2-macroglobulini (alpha2M) gene in rat ovarian granulose cells. MolecEtndo. 1998; 12:1393-1409.

[12] Emmerson DA, Denbow DM, Van Krey HP, Hulet RM, \& El Halawani ME. Protein and energy self-selection of turkey hens. Serum prolactin and LH concentrations. Comparative Biochemistry and Physiology. CompaPhysio. 1991; 100: 495-499.

[13] Porter TE, Silsby JL, Hargis BM, Fehrer SC, EL Halawani ME. Ovarian steroid production in vitro during gonadal regression in the turkey. II. Changes induced by forced molting. BiolReprod. 1991; 45: 587-591.

[14] Wang A, Hsuch JW, Erichron G. Prolactin inhibition of estrogen production by cultured rat granulose cells. Mol. Cell. Endocrinol. 1980; 20:135-144

[15] Dorrington R, Gore- Longton E. Prolectin inhibits oestrogen synthesis in the overy. Nature (Lond). 1981; 290:600-602.

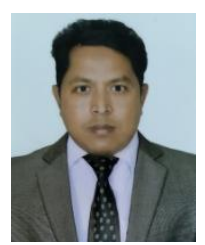

Md. Bazlar RASHID (PhD), Associate Professor, Dept. of Physiology \& Pharmacology, Hajee Mohammad Danesh Science and Technology University, Bangladesh. Date of Birth: 03 July 1980, Nationality: Bangladeshi (by birth). I have secured PhD on animal and food hygiene from Obihiro University of Agriculture and Veterinary Medicine, Obihiro, Japan, in 2018, MS in Physiology from Bangladesh Agricultural University (BAU), Mymensingh, Bangladesh in 2007 and DVM also from BAU, Mymensingh in 2005. I have a total of 18 publications in national and international reputed journals. I have operated nine projects funded by the government of Bangladesh as a principal investigator. I am skilled in Ovsynch protocol, MOET technique, Embryo collection and transfer, IVM IVF, In vitro embryo culture, Immune cells (PBMC \& PMN) separation \& culture, Bovine uterine cell culture, Immuno-histochemistry, Immunofluorescence, RNA extraction, cDNA synthesis, real-time PCR. I am highly interested in researching animal reproduction, especially cattle. My key 
focuses on immune cells that respond to the embryo to favor the immune environment during early pregnancy.

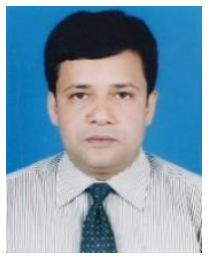

Dr. Md. Hakimul Haque is an Associate Professor in the Department of Veterinary and Animal Sciences,

Faculty of Agriculture at the University of Rajshahi, Bangladesh. Dr. Haque completed DVM from Bangladesh Agricultural University (BAU) in 2005. Later he completed a Master of Science (MS) in Microbiology from the BAU in 2007 and received a

$\mathrm{PhD}$ from the school of Medicine in collaboration with the School of natural science and Queensland Micro and Nanotechnology Centre, Griffith University in 2017 and a Postdoc from the Griffith University and University of Wollongong, Australia.

Dr. Haque's research has initially focused on bacteria, viruses, fungus, and parasites, to comprehend the impacts of disease damage to agricultural industries. He has worked on epidemiological, serological, and molecular characterization of bacterial, parasitic, and viral pathogens. This work is published in 28 journals at the national and international level. His $\mathrm{PhD}$ work identified several biomarkers and established their relationship for clinical and pathological use in diagnosing oesophageal squamous cell carcinoma. Subsequently, he has developed novel electrochemical and nanotechnology-based diagnostic biosensor platforms using Gold-DNA and Graphene-DNA affinity interactions. This work resulted in several Q1, and Q2 journal publications focused on multidisciplinary research. As a research team leader, Dr. Haque has worked as a supervisor and cosupervisor for $10 \mathrm{MS}$ and $\mathrm{PhD}$ students. 